\title{
Protective Effects of Ethanol Leaf-Extract of Cajanus Cajan (Linn) in Alcohol Induced Nephrotoxicity in Albino Rats
}

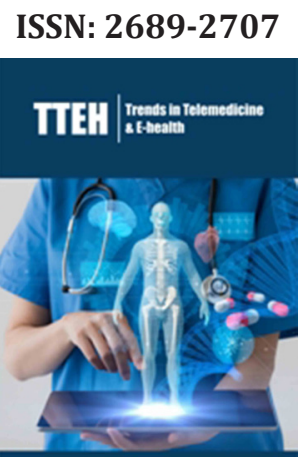

*Corresponding author: NN Ezeani, Department of Biochemistry, Nigeria

Submission: 僵 September 17, 2019

Published: 笽 November 08, 2019

Volume 2 - Issue 1

How to cite this article: CE Offor, NN Ezeani, R Iloegbunam, SEN Ukpabi, PM Aja, CO Ogbu . Protective Effects of Ethanol Leaf-Extract of Cajanus Cajan (Linn) in Alcohol Induced Nephrotoxicity in Albino Rats. Trends Telemed E-Health 2(1). TTEH. 000528. 2019.

DOI: 10.31031/TTEH.2019.02.000528

Copyright@ NN Ezeani, This article is distributed under the terms of the Creative Commons Attribution 4.0 International License, which permits unrestricted use and redistribution provided that the original author and source are credited.

\author{
CE Offor ${ }^{1}$, NN Ezeani ${ }^{1 *}$, R Iloegbunam ${ }^{2}$, SEN Ukpabi ${ }^{1}$, PM Aja $^{1}$ and CO Ogbu ${ }^{1}$ \\ ${ }^{1}$ Department of Biochemistry, Nigeria \\ ${ }^{2}$ Department of Chemical Pathology, Nigeria
}

\begin{abstract}
The protective effects of ethanol leaf-extract of Cajanus cajan in alcohol induced nephrotoxicity in albino rats were investigated. Thirty six albino rats were assigned into six (6) experimental groups $(A, B, C, D, E, F)$ with six rats in each group. Group A (Normal control) was administered normal saline only. Group B (standard control) was administere $5 \mathrm{mg} / \mathrm{kg}$ body weight of standard drug (Silymarin); group C (positive control) was administered $3.7 \mathrm{~g} / \mathrm{kg}$ body weight of $99.7 \%$ ethanol while rats in groups D,E and F (test groups) were administered graded doses of $200 \mathrm{mg} / \mathrm{kg}, 400 \mathrm{mg} / \mathrm{kg}$ and $600 \mathrm{mg} / \mathrm{kg}$ body weights of ethanol leaf-extract of Cajanus cajan respectively. Rats in standard control and test groups were administered $3.7 \mathrm{~g} / \mathrm{kg}$ body weight of $99.7 \%$ ethanol, once a day, 3 hours after administration of standard drug and ethanol leaf-extract of Cajanus cajan respectively. The administration lasted for 14 days through oral intubation. The result of our investigation showed that creatinine, uric acid and urea were significantly $(\mathrm{P}<0.05)$ increased in positive control group compared to the levels observed in the normal and standard control groups. However, groups administered ethanol leaf-extract of Cajanus cajan at the doses of $200 \mathrm{mg} / \mathrm{kg}, 400 \mathrm{mg} / \mathrm{kg}$ and $600 \mathrm{mg} / \mathrm{kg}$ body weight all showed a significant $(\mathrm{P}<0.05)$ reversal in the trends of these parameters to concentrations comparable to those observed in the positive and normal control groups. The findings of this study suggest that ethanol leaf-extract of Cajanus cajan may have potentials that could be exploited for development of chemotherapies against renal toxicity.
\end{abstract}

Keywords: Cajanus Cajan; Alcohol; Nephrotoxicity; Kidneys; Albino rats; Creatinine; Uric acid; Urea

\section{Introduction}

Cajanus cajan is a tropical woody herb with yellow flowers and is a perennial plant belonging to the family Leguminosae. It is commonly known as Pigeon pea in English, "Fiofio in Igbo", "Waken turawa" in (Hausa) and "Otili" in Yoruba Nigeria. It has a highly nutritious seed of the tropical Pigeon pea plant Luo et al. [1]. It has been cultivated in ancient Egypt, Africa and Asia. This plant was introduced in America and in other several tropical countries and it is mainly produced in India Mc Cuskey [2]. It is a nutritious non-toxic edible tropical legume with several desirable characteristics, widely used in Indian folk medicine for prevention of various liver disorders Luo et al. [1]. The pigeon pea leaf extracts may be valuable natural antioxidant sources and are potentially applicable in both medicine and healthy food industry Wu et al. [3].

Alcoholism is the most serious addictive disease prevalent in our society and accepted to be a worldwide drinking related health problem. Despite the obvious consequences of acute and chronic alcohol toxicity, the natural quest for alcohol consumption has made it "a free for all drink" Nwodo [4] and Kundua et al. [5]. The morbidity and mortality of diseases associated with alcohol intake is both a racial, social and health problem and the complication of kidney failure may be a double tragedy for alcoholics. Fatty liver, cirrhosis, kidney failure and hepatitis have been associated with high intake of alcohol Ewa \& Arthur [6] and Nwodo [4]. Alcohol-induced organ pathogenesis is due to the accumulation of toxic substances generated during alcohol metabolism, which in turn generates Reactive Oxygen Species (ROS) and other free radicals Moncada et al. [7] and Albano et al. [8]. This results to covalent modification of cellular macromolecules, morphological changes leading to tissue damage and kidney dysfunction Mc Cuskey [2] and Kundua et al. [5]. 
Residual products (urea, creatinine, uric acid, etc.) formed as a result of metabolic reaction of substances incoming into the body are removed from the blood by kidneys which are natural treatment system of the body Brenner \& Floyd [9]. In addition to this, kidneys can perform many vital functions such as regulation of water balance in the body and protection of body liquids (acidity/ alkalinity). Kidneys can filtrate about 200 liters of blood per day and remove toxic materials and excess liquid via 1.5 liters urine. Within this period, any imbalance occurred might cause disorder of kidney functions rapidly Agbafor et al. [10]. Kidney function disorder is resulted as accumulation of toxic substances in the blood that should be removed from the body Henry [11]. In practice, blood and urine tests are carried out for the assessment of kidney functions and determination of degree and level of function disorders. Such tests indicate to what extent kidneys are successful to filtrate these residual products and excess liquid in the body Shivaraj et al. [12]. Creatinine and Blood Urine Nitrogen (BUN) can be searched in a blood sample. As filtration process of kidneys decreases, the levels of these residual products increase in the blood. Abnormal results obtained are generally first indicators of kidney diseases Mehta \& Chertow [13].

Also, Creatinine is a breakdown product of creatine phosphate in muscle and is usually produced at a fairly constant rate by the body (depending on muscle mass). Serum creatinine (a blood measurement) is an important indicator of renal health because it is easily measured as a by-product of muscle metabolism that is excreted unchanged by the kidneys Lujambio et al. [14]. The typical human reference ranges for serum creatinine are $0.5-1.2 \mathrm{mg} /$ dl (about $45-90 \mu \mathrm{mol} / \mathrm{l}$ ) for adults male, $0.4-1.1 \mathrm{mg} / \mathrm{dl}$ (about $60-110 \mu \mathrm{mol} / \mathrm{l}$ ) and $0.0-0.7 \mathrm{mg} / \mathrm{dl}$ for children up to 12 years of age. Urine creatinine ranges for adult male is $20-25 \mathrm{mg} / \mathrm{kg} /$ day and for adult female $15-20 \mathrm{mg} / \mathrm{kg} /$ day Hille [15]. Increased creatinine levels are seen in impaired renal function, chronic nephritis, shocks and muscle atrophy can result in decreased creatinine level. Uric acid is a heterocyclic compound of carbon, nitrogen, oxygen and hydrogen with the formula $\mathrm{C}_{5} \mathrm{H}_{4} \mathrm{~N}_{4} \mathrm{O}_{3}$. It forms ions and salts known as urates and acid urates such as ammonium acid urate Heining \& Johnson [16]. In human blood plasma, the reference range of uric acid is typically $3.4-7.2 \mathrm{mg} / \mathrm{dl}(200-430 \mu \mathrm{mol} / \mathrm{l})$ for an adult male, $2.4-6.1 \mathrm{mg} / \mathrm{dl}$ for an adult female $(140-360 \mu \mathrm{mol} / \mathrm{l})$ and children range from 3-4mg/dl. Drugs such as Thiazide diuretic can increase uric acid level by interfering with renal clearance Slims [17]. Urea (Carbamide) is an organic compound with the chemical formula $\mathrm{CO}\left(\mathrm{NH}_{2}\right)_{2}$. The molecule has two- $\mathrm{NH}_{2}$ groups joined by a carbonyl $(\mathrm{C}=0)$ functional group. The liver forms urea by combing two ammonia molecules $\left(\mathrm{NH}_{3}\right)$ with a carbon dioxide $\left(\mathrm{CO}_{2}\right)$ molecule in the urea cycle. 7 to $20 \mathrm{mg} / \mathrm{dl}$ ( 2.5 to $7.1 \mathrm{mmol} / \mathrm{l}$ ) is considered normal range. For adult male is 8 to $20 \mathrm{mg} / \mathrm{dl}$, adult female 6 to $20 \mathrm{mg} / \mathrm{dl}$ and children 5 to $18 \mathrm{mg} / \mathrm{dl}$.

Extract from Cajanus cajan leaves have been reported to have antimicrobial, antibacterial, antidiabetic, anthelminthic, anticancer, antimalarial and neuroactive activities $\mathrm{Wu}$ et al. [3]. Sharafati \& Sherafati [18] also reported the antimicrobial activities of Cajanus cajan leaf extract against eight microbial strains (Staphylococcus epidermidis, Staphylococcus aureus, Bacillus subtilis, Proteus vulgaris, Pseudomonas aeruginosa, Escherichia coli; and fungi, Aspergillus niger and Candida albicans). Despite the reports above, there are still very limited publications on the nephroprotective effects of Cajanus cajan leaf extracts. The data generated from this present study would go a long way to increasing the volume of information about the potential uses of this plant, especially as it relates to its protection against renal toxicity.

Cajanus cajan preparations are often recommended for the treatment of several organ disorders by most herbalists in Nigerian traditional societies and quite often claimed to have offered significant relief to patients. In attempt to get more scientific evidence for this traditionally reported herbal drug, our attentions were aroused to carry out this study to investigate the protective effects of ethanol leaf-extract of Cajanus cajan in alcohol induced nephrotoxicity in albino rats.

\section{Aim/Objectives}

The aim of this study was to investigate the protective effects of ethanol leaf-extract of Cajanus cajan (Linn) in alcohol induced nephrotoxicity in male albino rats.

\section{Material and Method}

\section{Material}

Fresh leaves of Cajanus cajan were collected from NdeguObu village in Ameffia Ngbo in Ohaukwu Local Government Area of Ebonyi State, Nigeria in the month of July. The experimental animals used in this study were albino rats purchased from the animal unit of Faculty of Veterinary Medicine, University of Nigeria, Nsukka, Enugu state, Nigeria. All chemicals and reagents used were of analytical standard.

\section{Method}

Urea was measured according to the method described by Allian et al. [19]. Creatinine was measured according to the method of Burtis [20]. Uric acid was measured according to the method of Barham [21].

\section{Experimental Design}

A total of thirty-six (36) albino rats were used in this study. The rats were randomly assigned into six (6) experimental groups of A,B,C,D,E and F with six (6) rats in each group after acclimatization for 7 days: Group A (normal control) was given normal saline only. Group B (standard control) was administered standard drug (silymarin) at the dose of $5 \mathrm{mg} / \mathrm{kg}$ body weight and co-administered absolute ethanol $(3.7 \mathrm{~g} / \mathrm{kg}$ body weight) 3 hours later. Group C (positive control) was administered absolute ethanol of $3.7 \mathrm{~g} / \mathrm{kg}$ body weight of the rats only. Groups D,E and F (Test groups) were administered graded doses of 200,400 and $600 \mathrm{mg} / \mathrm{kg}$ body weight of ethanol leaf extract of $C$. cajan respectively and absolute ethanol of $3.7 \mathrm{~g} / \mathrm{kg}$ body weight 3 hours later. This administration lasted for 14 days through oral intubation. They were all fed with grower's marsh and water ad libitum. 


\section{Collection of Blood Sample}

After 14 days of administration, the rats were mildly anesthetized using chloroform, blood sample were collected from the albino rat by femoral vein puncture method.

\section{Result}

Data are shown as Mean \pm Standard Deviation $(n=6)$. Mean values with different alphabet showed significant difference at $\mathrm{p}<0.05$ in the figures.

\section{Discussion and Conclusion}

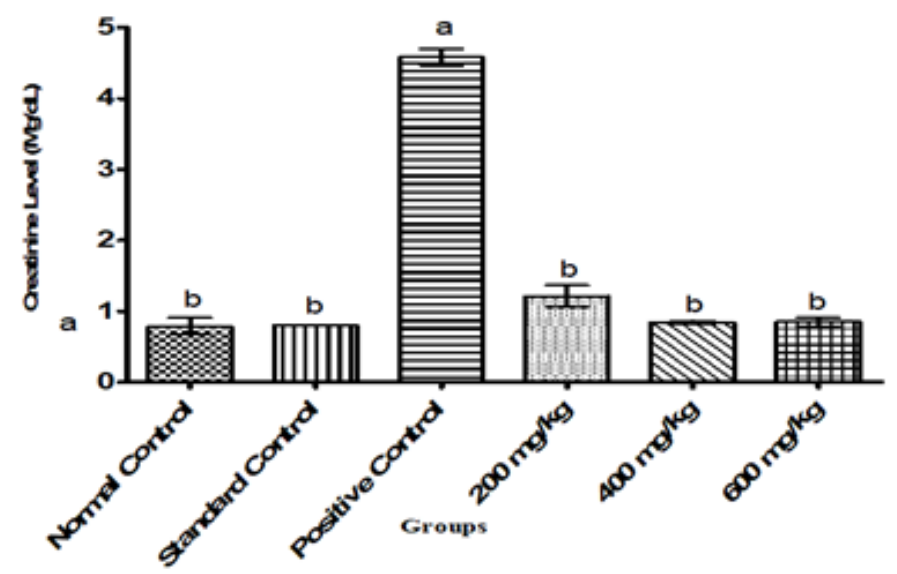

Figure 1: Creatinine level in Albino Rats Administered Ethanol-Leaf Extract of Cajanus cajan.

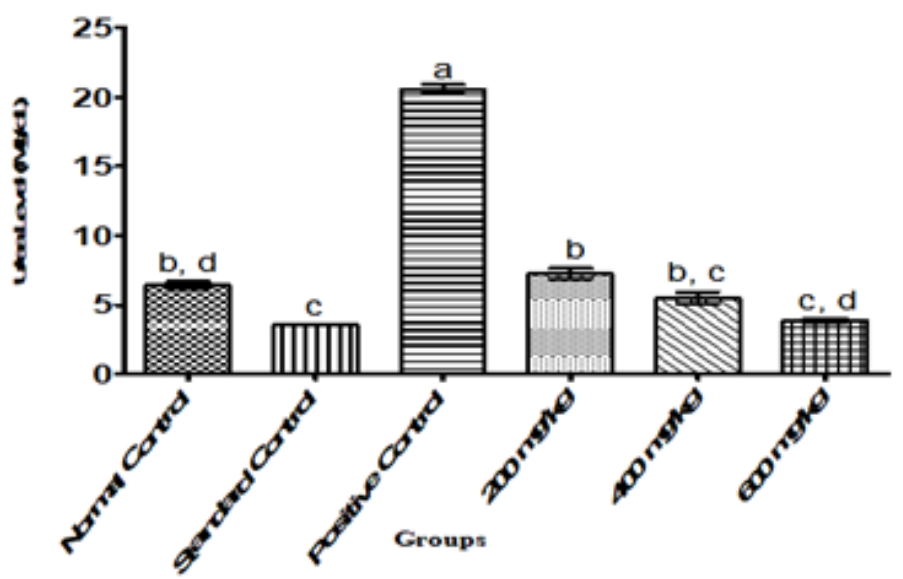

Figure 2: Urea level in Albino Rats Administered Ethanol-Leaf Extract of Cajanus cajan.

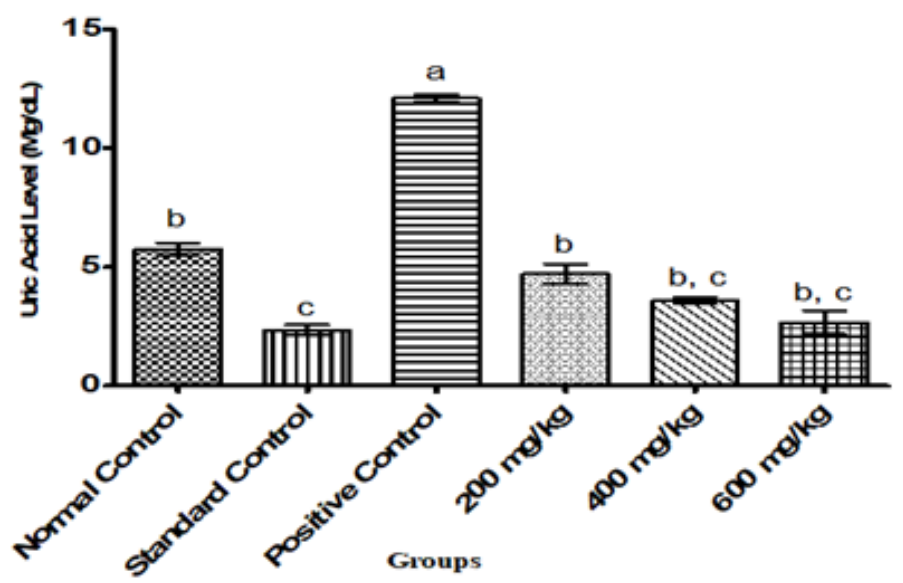

Figure 3: Uric acid level in Albino Rats Administered Ethanol-Leaf Extract of Cajanus cajan. 
In general, parameters of renal function and fluid homeostasis investigated in this study gave some significant results. The positive control showed a significant $(\mathrm{P}<0.05)$ increase in the levels of creatinine, urea and uric acid relative to normal and standard control groups. However, administration of ethanol leaf extract of Cajanus cajan at the graded doses of 200,400 and $600 \mathrm{mg} / \mathrm{kg}$ body weight of the rats showed a significant $(\mathrm{P}<0.05)$ reversal in the trend of these kidney biomarkers to levels comparable to those observed in normal and positive control groups as shown in Figure 1-3 respectively.

The positive control showed a significant $(\mathrm{P}<0.05)$ increase in the levels of creatinine relative to levels seen in normal and standard control groups. However, administration of ethanol leaf extract of Cajanus cajan at the graded doses of 200,400 and $600 \mathrm{mg} / \mathrm{kg}$ body weight of the rats showed a significant $(\mathrm{P}<0.05)$ reversal in the trend of creatinine to levels comparable to those observed in normal and positive control groups as shown in Figure 1. Agbafor et al. [22] showed an insignificant decrease $(\mathrm{P}>0.05)$ in concentrations of creatinine in the animals given the leaf-extract when compared to the control group. These effects were found to be in dose dependent manner. Ahamefule et al. [23] reported a study on rabbits fed with raw pigeon pea seed based diets in a completely randomized design to ascertain remarkable changes in haematological and biochemical profile for weaner rabbits. The result of their study showed that among the parameters not affected $(\mathrm{P}>0.05)$ by diets were blood urea, creatinine, bilirubin, total protein, SGOT and SGPT concentrations. The variations in the results of Ahamefule et al. [23] with that obtained in the present study may be attributed to the difference in methodology, experimental animal model, doses of the extract or different species of the plant used. Serum creatinine is an indicator of renal health because it is an easily measured by product of muscle metabolism that is excreted unchanged by the kidney. If the kidney is deficient in its filtration ability, creatinine blood level rises Ahamefule et al. [23]. Since the result of this research showed a decrease in creatinine level due to administration of Cajanus cajan leaf-extract, the extract could be assumed to be nephroprotective.

Madinah et al. [24] used Carica papaya to investigate the protective effect of aqueous extract of Carica papaya seeds in paracetamol induced nephrotoxicity in male Wister rats which showed a decrease in concentration of uric acid, creatinine and urea. From this present study, the result obtained showed a significant $(\mathrm{P}<0.05)$ decrease in urea concentrations of uric acid, creatinine and urea in the test groups when compared to the positive control as shown in Figure 2. The result of this study therefore suggests that Cajanus cajan leaf- extract has more potential to decrease urea level than Carica papaya as reported by Madinah et al. [24]. Urea plays an important role in the metabolism of nitrogen-containing compounds by animal and is the main nitrogen-containing the substance in the urine of mammals, when urea level is high in the blood tissue breakdown tissue can result e.g. hemorrhage Murray et al. [25]. Urea arises principally as a bye product of amino acid deamination and is the main route of nitrogen excretion Agbafor et al. [22].
The biochemical explanation for the significant decrease $(\mathrm{P}<0.05)$ in the level of uric acid in test groups when compared to positive control (Figure 3 ) is that the decrease may be as a result of the presence of some compounds such as flavonoids and anthocyanins, a chemical constituent present in the leaf extract of Cajanus cajanas reported by Agbafor et al. [22].

In conclusion, the present study showed that the ethanol-leaf extract of Cajanus cajan is capable of lowering kidney function parameters such as creatinine, urea and uric acids [26]. The result of this present investigation therefore suggests that ethanol leafextract of Cajanus cajan may have potentials that could be exploited for development of chemotherapies to manage and/or treat renal toxicity.

\section{References}

1. Luo QF, Sun L, Si JY, Chen DH (2008) Hypocholesterolemic effect of stilbenes containing extract fraction from Cajanus cajan $L$. on diet induced hypercholesterolemia in mice. Phytomedicine 15(11): 932-939.

2. Cuskey RS (1991) In vivo microscopy of the effects of ethanol on the liver. In liver pathology and alcohol. Liver Pathology and Alcohol pp. 563-574.

3. Wu X, Beecher GR, Holden JM, Haytowitz DB, Gebhardt SE, et al. (2004) Lipophilic and hydrophilic antioxidant capacities of common foods in the United States. Journal of Agriculture and Food Chemistry 52(12): 4026-4037.

4. Nwodo OFC (1999) Alcohol. Nigeria p. 54.

5. Kundu R, Suman D, Anindita B, Anirban B, Bikas CP, et al. (2008) Cajanus cajan Linn. (Leguminosae) prevents alcohol-induced rat liver damage and augments cytoprotective functions. Journal of Ethnopharmacology 118(3): 440-447.

6. Ewa K, Arthur I (1996) Ferritin stimulation of lipid peroxidation by microsomes after chronic ethanol treatment: Role of cytochrome P450E1. Archives Biochemical Biophysics 332(1): 121-127.

7. Moncada C, Torres V, Varghese G, Albano E, Israel Y (2014) Ethanol derived immunoreactive species formed by free radical mechanisms. Journal of Molecular Pharmacology 46(4): 786-791.

8. Albano E, French SW, Sundberg IM (1999) Hydroxyethyl radicals in ethanol hepatotoxicity. Frontiers in Bioscience 4: 533-540.

9. Brenner BM, Floyd CR (1999) The Kidney. ( $6^{\text {th }}$ edn), USA.

10. Agbafor KN, Engwa AG, Ude CM, Obiudu IK, Festus BO (2015) Effect of aqueous leave extract of Ageratum Conyzoides on blood glucose, creatinine and calcium ion levels in albino rats. Journal of Pharmaceutical Chemical and Biological Sciences 3(3): 408-415.

11. Henry JB (2001) Clinical diagnosis and management by laboratory methods. (20 $0^{\text {th }}$ edn), USA.

12. Shivaraj G, Prakash BD, Shruthi SK, Vinayak VH, Avinash AKM, et al. (2010) Markers of renal function test. American Journal of Medical Science 2(4): 170-173.

13. Mehta RL, Chertow GM (2003) Acute renal failure definitions and classification: Time for change. Journal of American Society of Nephrology 14(8): 2178-2187.

14. Lujambio I, Sottoiano M, Luzardo L, Knil N, Robaina S, et al. (2014) Estimation of glomerular filtration rate based on serum cystain c versus creatinine in a Uruguayan population. International Journal Nephrology 79(8): 37-106.

15. Hille R (2005) Molybdenum-containing hydroxylases. Archives of Biochemistry and Biophysics 433(1): 107-116. 
16. Heining M, Johnson RJ (2006) Role of uric acid in hypertension renal disease and metabolic syndrome. Cleave land Clinical Journal of Medicine 73(12): 1059-1064.

17. Slims GK (2006) Using the Berthelot method for nitrite and nitrate analysis. Soil Science Society American Journal 70(3): 1038.

18. Sharafati R, Sherafati F, Rafieian KM (2011) Biological characterization of Iranian walnut (Juglans regia) leaves. Turkish Journal of Biology 35 635-639.

19. Allian CC, Poon LS, Chan CSG, Richmond W, Fu PC (1978) Enzymatic determination of total serum urea. Journal of Clinical Chemistry 20(2): 470-475.

20. Burtis CA (2008) Tietz fundamentals of clinical chemistry. ( $6^{\text {th }}$ edn), USA, pp. 10-27.

21. Barham T (1972) Enzymatic colorimetric determination of uric acid Journal of Clinical Chemistry 97(2): 142-144.
22. Agbafor KN, Nwaka AC, Dasofunjo K, Asuk AA, Ugwu MN (2017) Creatinine, urea and uric acid levels in albino rats treated with leaf extract of Cajanus cajan (pigeon pea). Journal of Applied Sciences 2(2): $1-9$.

23. Ahamefule FO, Obua BE, Ukweni IA, Oguike MA, Amaka RA (2008) Haematological and biochemical profile of weaner rabbits fed raw or processed pigeon pea seed meal based diets. African Journal of Agricultural Research 3(4): 315-319.

24. Madinah N, Nozomo M, Ezekiel L (2015) The protective effects of aqueous extract of Carica papaya seeds in paracetamol induced nephrotoxicity in male wistar rats. Journal of African Health Sciences 15(2): 598-605.

25. Murray RK, Granuer DK, Mayes PA, Rodwell VW (2003) Harper's biochemistry. (25 ${ }^{\text {th }}$ edn), USA, p. 111.

26. Papadakis MA, Arieff AI (1987) Unpredictability of clinical evaluation of renal function in cirrhosis. Prospective study. American Journal Medicine 82(5): 945-952.

For possible submissions Click below: 